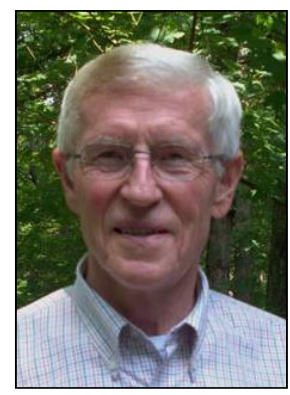

THE ECONOMIC PAMPHLETEER

JOHN IKERD

\title{
The battle for the future of food
}

Published online August 30, 2018

Citation: Ikerd, J. (2018). The battle for the future of food. Journal of A griculture, Food Systems, and Community D evelopment, 8(3), 9-12. http:// dx.doi.org/ 10.5304/ jafscd.2018.083.006

Copyright (C) 2018 by the Author. Published by the Lyson Center for Civic Agriculture and Food Systems. Open access under CC BY license.

W e are in the midst of a battle for the future of our food systems. In spite of persistent denials, today's so-called modern food system simply cannot be sustained for much longer. Mounting evidence of the negative impacts of today's dominant systems of food production on the natural environment, public health, animal welfare, and the quality of rural life is becoming difficult to deny or ignore.

The U.S. Environmental Protection Agency

John Ikerd is professor emeritus of agricultural economics, University of Missouri, Columbia. He was raised on a small farm and received his BS, MS, and PhD degrees from the University of Missouri. He worked in the private industry prior to his 30-year academic career at North Carolina State University, Oklahoma State University, the University of Georgia, and the University of Missouri. Since retiring in 2000 , he spends most of his time writing and speaking on issues of sustainability. Ikerd is author of six books and numerous professional papers, which are available at http:/ / johnikerd.com and http:/ / faculty.missouri.edu/ ikerdj/
(U.S. EPA) consistently identifies agriculture as the leading nonpoint source of pollution of rivers and streams and a major contributor to pollution of lakes, wetlands, estuaries, and groundwater (U.S. EPA, n.d.). Massive "dead zones," such as those in the G ulf of Mexico and Chesapeake Bay, developed with the industrialization of American agriculture (National G eographic Society, 2011). Agriculture has also been identified as a major contributor to global climate change. Experts disagree, but an emerging consensus seems to be

Why an Economic Pamphleteer? Pamphlets historically were short, thoughtfully written opinion pieces and were at the center of every revolution in western history. I spent the first half of my academic career as a freemarket, bottom-line agricultural economist. During the farm financial crisis of the $1980 \mathrm{~s}$, I became convinced that the economics I had been taught and was teaching wasn't working and wasn't going to work in the futurenot for farmers, rural communities, consumers, or society in general. Hopefully my "pamphlets" will help spark the needed revolution in economic thinking. 
that agriculture globally contributes about $15 \%$ of human-caused greenhouse gas emissions- about the same as transportation (Nahigyan, 2016). Animal agriculture is a major contributor, and environmentalists have joined animal welfare advocates in calling for an end to industrial animal agriculture.

Agricultural pollution has also become a major public health issue. In 2015, the World Health Organization concluded that glyphosate, the world's most widely used agricultural pesticide, is "probably carcinogenic to humans" (International Agency for Research on Cancer, World Health Organization, 2015). Numerous scientific studies confirm that residues of glyphosate are ubiquitous in the air, soil, water, food, and even in our bodies (Watts, Clausing, Lyssimachou, Schütte, Guadagnini, \& Marquez, 2016). Health risks are not limited to agricultural chemicals. Scientists around the world have confirmed that the routine use of antibiotics in largescale confinement animal operations is a significant contributor to the rise in human infections by antibiotic-resistant bacteria, such as the deadly MRSA. The U.S. Centers for D isease Control and Prevention (2013), the World Health O rganization (2016), and a special Summit Meeting on the United Nations (General Assembly of the United Nations, 2016) have all called for significant restrictions or bans on the routine use of antibiotics in livestock operations for growth promotion and disease prevention rather than treatment.

The dominant systems of food production are becoming indefensible. The fundamental question is whether to try to fix the current system or instead to replace it. The dominant players in the food system are trying to fix it, as replacing it would mean losing their position of dominance. Virtually every major agri-food corporation now includes sustainability in its mission statement and issues an annual sustainability report to convince its investors and customers that the corporation is responding to growing public concerns. The industrial agriculture establishment is attempting to restore confidence and trust through a multimillion dollar public-relations campaign funded by agrifood corporations and mainstream agricultural organizations (Hamerschlag, Lappé, \& Malkan, 2015). The U.S. Farmers and Ranchers Alliance, for example, with a budget of US\$11 million in 2011 , is one of more than a dozen industry front groups formed specifically to restore the tarnished public image of "modern agriculture" (Ruskin, 2015).

In addition, the large agri-food corporations are modifying their production practices, when deemed economically feasible, to temper public demands for stricter government regulations. Both Tyson and Purdue have announced plans to stop using antibiotics in their poultry operations

(Amelinckx, 2017). Walmart recently joined McD onald's on a growing list of food markets and restaurants announcing intentions to source eggs only from "cage-free" poultry operations (Pacelle, 2017). O rganic food production has been embraced by large agri-food corporations - after they found ways to industrialize and dominate the organic movement (Ikerd, 2018). Industrial producers of row crops are promising to reduce agricultural pollution of streams and aquifers, if they are given government funds as an incentive and additional time to implement voluntary programs (Environmental and Energy Study Institute, 2016).

In the meantime, most agriculture producers are relying on the currently accommodating regulatory environment to maintain the industrial status quo, including special right-to-farm laws. All 50 states have some type of legislation that protects agricultural producers from nuisance lawsuits by neighbors who are adversely affected by their operations (Weldon \& Rumley, n.d.). A recent trend in right-to-farm legislation has been to expand protection explicitly to industrial farming systems, such as concentrated animal feeding operations 
(CAFOs) and genetically modified crops. Model legislation developed by the American Legislative Exchange Council is being used in many agricultural states (The Center for Media D emocracy, 2017).

These and other attempts to defend and protect industrial agriculture tend to focus on separating and insulating agriculture from the ecological and social environment in which farms must function. Confinement livestock and poultry operations remove animals from their natural habitat and isolate them physically and visually from public exposure. Hydroponic vegetable production removes crop production from reliance on soil fertility as well as the vagaries of climate and weather. G enetic engineers are attempting to weatherproof crops. Farming by GPS-guided robots and drones would reduce future needs for farmworkers and the associated risks to public health. Advocates extoll the environmental and social benefits of such innovations. The basic question is whether separation or shielding from nature and society results in better systems or simply hides their fundamental flaws from public view. Regardless, if the battle for the future of food is to be won by the industrial agri-food system, it seems agriculture must be essentially separated from nature and society.

The logical altemative is to replace industrial agriculture with a fundamentally different model of agri-food production that would reconnect agriculture with nature and society. Today, this alternative model goes by various names, including organic, ecological, biological, biodynamic, sustainable, resilient, regenerative, and restorative agriculture, as well as permaculture, holistic management, and nature farming. The unifying principle of all of these alternatives is their recognition and respect for the inherent interconnectedness of agriculture with its natural environment- with the air, water, soil, and energy flow of nature.
These alternatives share common roots in the scientific principles of agroecology, which applies the science of ecology to agriculture (Altieri, n.d.). Ecology is a study of the relationships of living organisms, including humans, with the other elements of their natural and social environment. In living systems, all things are interconnected. All elements of farming - soil, plants, animals, workers, farmers - are interrelated with everything else.

Farms also are connected integrally with the natural bioregions and social communities within which, and for which, they function. Agri-food economies, being creations of societies, are but one dimension of the agroecological environment. When agroecological farmers do any one thing, they are aware that other things may be affected on their farms as wholes as well as in their bioregions and communities.

Agroecology was the natural model of choice for the global food sovereignty movement, which proclaims "the right of peoples to healthy and culturally appropriate food produced through ecologically sound and sustainable methods, and their right to define their own food and agriculture systems" (Nyéléni, 2007, quoted in Ikerd, 2015, p. 13). Perhaps more relevant in the U.S., agroecology provides a science-based conceptual foundation for the local food movement, which could well evolve into the primary contender with industrial agriculture for the future of food (Ikerd, 2017).

The sustainable alternative to today's industrial agri-food system is less well defined because it is a diverse, individualistic, dynamic, emerging agroecological system. Regardless, the battle for the future of food is between those attempting to separate and insulate today's industrial agri-food system from nature and society and those who are striving to create a sustainable agri-food system that functions in harmony with its ecological, social, and economic environment. 


\section{References}

Altieri, M. A. (n.d.). A groeology: Principles and strategies for designing sustainable farming systems. Retrieved from the Agroecology in Action website: http:/ / www.agroeco.org/ doc/ new docs/Agroeco_principles.pdf

Amelinckx, A. (2017, March 9). Big Chicken goes antibiotic-free. M odern Farmer. https:/ / modernfarmer.com/ 2017/ 03/ big-chicken-goes-antibiotic-free/

Center for Media D emocracy, The. (n.d.). Right to farm laws. SourceWatch. Last updated O ctober 4, 2017, and retrieved August 22, 2018, https:/ / www.sourcewatch.org/ index.php/ Right_to_Farm_Laws

Centers for Disease Control and Prevention. (2013). A ntibiotic resistanœ threats in the U nited States, 2013. https:/ / www.cdc.gov/ drugresistance/ threat-report-2013/ pdf/ ar-threats-2013-508.pdf

Environmental and Energy Study Institute. (2016, February 26). In federal, state and private initiatives to improve water quality, no dear answers. Retrieved from https:/ / www.eesi.org/ articles/ view/ in-federal-state-and-private-initiatives-toimprove-water-quality-no-clear-

General Assembly of the United Nations. (2016, September 21). H igh-level meeting on antimicrobial resistance [Press release]. Retrieved from https:/ / www.un.org/ pga/ 71/ 2016/ 09/ 21/ press-release-hl-meeting-on-antimicrobial-resistance/

Hamerschlag, K., Lappé, A., \& Malkan, S. (2015). Spinning food: H ow food industry front groups and covert communications are shaping the story of food. Friends of the Earth. Retrieved from http:// www.foe.org/ projects/ food-andtechnology/ good-food-healthy-planet/ spinning-food\#sthash.8X hj3lat.dpuf

Ikerd, J. (2015). Food sovereignty: A new mandate for food and farm policy. Journal of A griculture, Food Systems, and Community D evelopment, 5(2), 11-14. http:// dx.doi.org/ 10.5304/ jafscd.2015.052.004

Ikerd, J. (2017). Soul of the local food movement. Journal of A grialture, F ood Systems, and C ommunity D evelopment, 7(4), 5- 7. http:/ / dx.doi.org/ 10.5304/ jafscd.2017.074.002

Ikerd, J. (2018). The industrialization of organics. Journal of A griculture, F ood Systems, and Community D evelopment, 8(1), 9-12. http:// dx.doi.org/ 10.5304/ jafscd.2018.081.001

International Agency for Research on Cancer, World Health O rganization. (2015). E valuation of five organophosphate insecticides and herbicides (IARC Monograph Volume 112). Retrieved from http:// www.iarc.fr/ en/ mediacentre/ iarcnews/ pdf/ MonographV olume112.pdf

Nahigyan, P. (2016, February 9). H ow much does agriaulture contribute to global warming? Planet Experts. Retrieved from http:/ / www.planetexperts.com/ how-much-does-agriculture-contribute-to-global-warming/

National Geographic Society. (2011). D ead zone. Retrieved from https:// www.nationalgeographic.org/ encyclopedia/ dead-zone/

Pacelle, W. (2016, April 5; updated 2017, D ecember 6). Breaking news: Walmart, the nation's biggest food seller, says no to cage confinement for hens [Blog post]. H uffington Post. Retrieved from https:/ / www.huffingtonpost.com/ entry/ breaking-news-walmart-the b 9620272.html

Ruskin, G . (2015, January 21). U.S. F armers and Ranchers A lliance- Key facts. U.S. Right to Know. https:/ / usrtk.org/ hallof-shame/ us-farmers-and-ranchers-alliance/

U.S. Environmental Protection Agency [EPA]. (n.d.). Polluted runoff; N onpoint sourœ (N PS) pollution: N onpoint sourœ: A griculture. Retrieved January 2017 from https:/ / www.epa.gov/ nps/ nonpoint-source-agriculture

Watts, M., Clausing, P., Lyssimachou, A., Schütte, G., Guadagnini, R., \& Marquez, E. (2016). G lyphosate [Monograph]. Pesticide Action Network. Retrieved from http:/ / pan-international.org/ wp-content/ uploads/ Glyphosatemonograph.pdf

Weldon, K., \& Rumley, E.. (n.d.). States' right-to-farm statutes. The National Agricultural Law Center. http:/ / nationalaglawcenter.org/ state-compilations/ right-to-farm/

World Health Organization. (2017, November 7). Stop using antibiotics in healthy animals to prevent the spread of antibiotic resistanc [News release]. Retrieved from http:// www.who.int/ mediacentre/ news/ releases/ 2017/ antibiotics-animalseffectiveness/ en/ 